\title{
Distance Learning Perspective in Turkey and Kurıkkale University: A Case Study
}

\author{
Mahmut Ünver, Atilla Ergüzen \\ Department of Computer Programming, Kırıkkale University, Kırıkkale, Turkey
}

\section{ABSTRACT}

In the early days, the distance learning (DL) process, which started with writing, has become quite common with applications from radio, television, computer and mobile devices until today. At the same time, distance learning is a teaching process starting from childhood and where people of all ages can receive education. Therefore, the number of people receiving education by distance learning method has increased considerably. Both in Turkey and globally, particularly in undergraduate and graduate levels, distance learning is widely used.

In this study, distance learning structure of Kirıkkale University, which provides distance learning services at associate and undergraduate level, has been examined. At Kurıkkale University, where the distance learning software is developed by its own staff, students are provided with written, audio and visual educational materials. Thanks to the weekly managed virtual classrooms, a strong communication between instructors and students, such as face-to-face education model, is ensured. Mid-term exams are conducted online, and final exams are conducted under the supervision of the instructor at the school. Online exams are made available through a module within the Learning Management System (LMS). Likewise, the forum and chat modules are integrated into the LMS, where the students can communicate with each other and with the instructors, students can find solutions to their problems easily.

Kirıkkale University provided an opportunity for people who could not receive formal education. The use of distance learning in the university has led to the introduction of a large number of distance learning materials and technologies and also has led to an increase in the level of formal education.
Key Words: Distance Learning, Learning

Management System, Virtual Classroom, Formal

Education.

\section{INTRODUCTION}

Distance Learning, which was first mentioned in the University of Wisconsin's 1892 Catalog, was used for the first time in a paper written by William Lighty, the director of the same university in 1906. This term (Fernunterricht) was introduced by German educator Otto Peters in Germany in the 1960s and 1970s and in France, it is practiced as a name (Teleenseignement) for distance learning institutions [1-2].

Technological developments are limited in the period when distance learning is introduced. Therefore, the educational activities carried out by the student and the instructor without any co-operation were realized by letter. The first systematic application of distance learning was implemented by Isaac Pitman in England. Pitman, who lived in the 1800 s, gave steno lectures through letters. Besides, the first organized distance learning activity was started in Germany. The language school "De Langenscheid", founded in 1856, has provided distance learning [1-3].

In Turkey, distance learning, has already been discussed conceptually in 1960 up to 1973. After 1970s, distance learning studies were conducted at secondary education level with different initiatives a number of experiences have been acquired and progress has been made, albeit limited. After 1980 these applications were moved to higher education with the establishment of Anadolu University Open Education Faculty. From the beginning of the 1990s to the beginning of the 2000s, the educational opportunities offered by distance learning with the developments in the field of information and information communication technologies

(ICT) 
increased and distance learning has been a part of the mainstream in education with the number of thousands of students in Turkey [4].

In the literature, although there are studies on the historical development of distance learning, the technologies used in distance learning, the benefits and limitations of distance learning; there are not many studies on the target of groups, aims, distance learning programs. In with this study, some higher education institutions and training programs under distance learning applications in the world and the current state of distance learning in Turkey, the number of students and some other important properties were investigated [5-10].

\section{FEATURES OF DISTANCE LEARNING}

$>$ Distance learning is independent of time. An individual can continue his / her education at any time by choosing the most suitable time. In this education system, how to use the time interval to complete the trainings is entirely up to the student.

$>$ Distance learning is also independent of the environment. In other words, individuals with inadequate educational opportunities or financial difficulties cannot continue their education where they live, and they can achieve the quality they want without changing the quality they want. In this way, one of the biggest problems of the education system, "equality of opportunity in education" is fully ensured.

$>$ With distance learning, the students are aware that they are taking lessons for their own personal development and that they take the courses at their own discretion and at intervals determined by them, so that the students behave more responsibly. The initiative is in the hands of the student in distance learning.

$>$ There is no obligation to take distance learning individually. In distance learning, it is possible to take part in joint projects and exchange information between students and instructors using the facilities of information technologies such as e-mail, forum, chat [11].

\section{CURRENT STATUS OF DISTANCE LEARNING IN TURKEY}

Turkey is a country acquainted distance learning quite late compared to developed European countries. Today, however, the opposite of this situation is experienced. In particular, the distance learning in Turkey, has entered a phase of rapid development together with the Anadolu University Open Education Faculty's establishment. However, the progress of Turkey's communications infrastructure, technology and increase in the amount of investment, are among the other factors that expansion of distance learning. Continuous development of the Internet in Turkey and to usage web-based remote applications in education has led to a more conscious education policy is intended. Through the Internet, many communication technologies are gathered in a single environment. Users can access printed resources, audio and video content via the internet [12].

Distance learning in Turkey is mainly applied to undergraduate and postgraduate level. In Table 1 and Table 2, number of available programs and opened quotas for university entrance exams in Turkey in 2012 and 2017 is shown. According to this Table 1, the number of distance learning quotas increased by $31,72 \%$ between $2012-2017$.

Table 1: University entrance examination quotas in 2012 and 2017 in Turkey

\begin{tabular}{|c|c|c|c|c|c|}
\hline \multicolumn{2}{|c|}{} & \multicolumn{2}{c|}{ Associate Degree } & \multicolumn{2}{c|}{ Undergraduate Degree } \\
\cline { 3 - 6 } \multicolumn{2}{c|}{} & Turkey & Kirikkale University & Turkey & Kirikkale University \\
\hline \multirow{2}{*}{2012} & Total Quota & 364,612 & 2,715 & 517,360 & 3,455 \\
\cline { 2 - 6 } & DL Quota & 8,811 & 200 & 3,359 & 0 \\
\hline \multirow{2}{*}{2017} & Total Quota & 556,432 & 3,877 & 527,817 & 4,648 \\
\cline { 2 - 6 } & DL Quota & 11,606 & 618 & 1,540 & 0 \\
\hline
\end{tabular}

Table 2: Distance learning program numbers of Turkey Universities by years.

\begin{tabular}{|c|c|c|c|c|}
\hline \multicolumn{2}{|c|}{} & \multicolumn{2}{|c|}{ Number of Academic Programme } \\
\cline { 3 - 5 } \multicolumn{2}{|c|}{} & Goverment Universities & Foundation Universities & Total \\
\hline 2010 & Associate Degree & 56 & 10 & 66 \\
\hline & Undergraduate Degree & 24 & 4 & 28 \\
\hline 2017 & Associate Degree & 86 & 23 & 109 \\
\hline & Undergraduate Degree & 11 & 4 & 15 \\
\hline
\end{tabular}


International Journal of Trend in Scientific Research and Development (IJTSRD) ISSN: 2456-6470

In Fig. 1 and Fig. 2, in 2012 and 2017, the quota graphs that compare the number of formal education and distance learning in Turkey is shown. According to these graphs, distance learning quotas increased at a higher rate than formal education quotas.

In Fig. 1 and Fig.2, the number of students, are trained in different programs in Turkey. The number of programs is shown in Table 2. In addition, in Table 3 and Table 4, a list of the distance learning programs obtained from the websites of the Higher Education Institution and universities has been established. Table 3 lists associate degree programs and Table 4 lists undergraduate programs $[12,13]$.
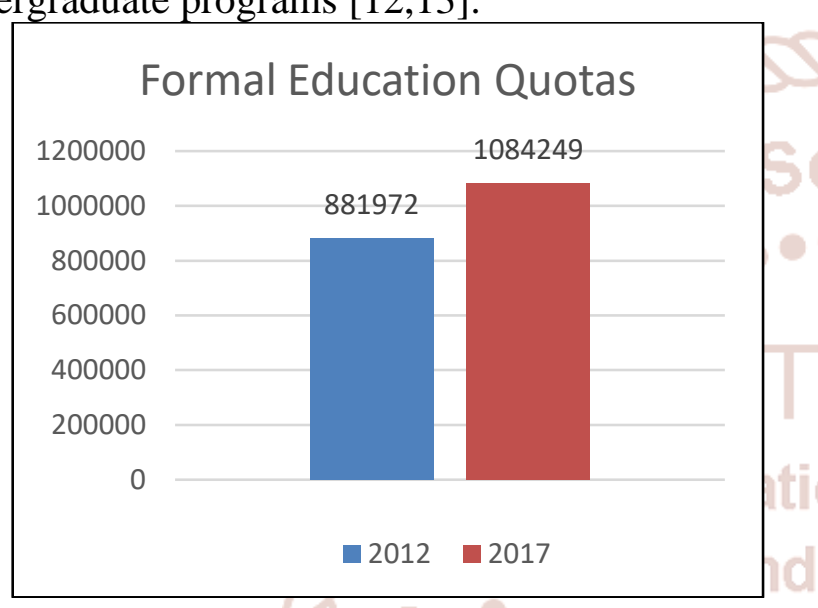

Figure.1: Formal Education Quotas Graph

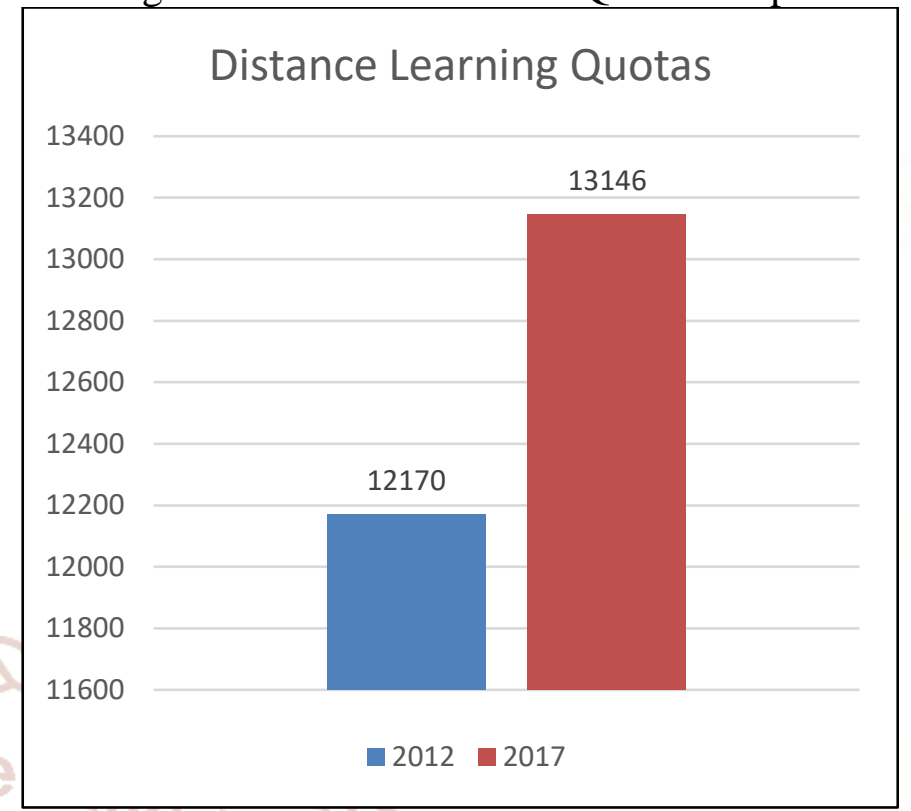

Figure 2: Distance Learning Quotas Graph

Table 3: Distance learning associate degree program in Turkey (2012)

\begin{tabular}{|c|l|c|}
\hline Order & \multicolumn{1}{|c|}{ Program Name } & Number \\
\hline 1 & Justice & 3 \\
\hline 2 & Hospitality Services & 1 \\
\hline 3 & Banking and Insurance & 2 \\
\hline 4 & Information Management & 6 \\
\hline 5 & Computer programming & 11 \\
\hline 6 & Computer technology and programming & 8 \\
\hline 7 & Computer technology & 3 \\
\hline 8 & Geographic Information Systems & 1 \\
\hline 9 & Child Development (Mixed Education) & 1 \\
\hline 10 & Child Development & 2 \\
\hline 11 & Foreign trade & 2 \\
\hline 12 & Drugstore Services & 2 \\
\hline 13 & Electronic Communication Technology & 1 \\
\hline 14 & Electronic Communication & 1 \\
\hline 15 & Electronic Technology & 1 \\
\hline 16 & Industrial Electronics & 2 \\
\hline 17 & Industrial automation & 1 \\
\hline 18 & Food Quality Control and Analysis & 1 \\
\hline 19 & Public Relations and Publicity & 1 \\
\hline 20 & Internet and Network Technologies & 1 \\
\hline
\end{tabular}




\begin{tabular}{|c|l|c|}
\hline 21 & Worker's health and work safety & 1 \\
\hline 22 & Business Management & 11 \\
\hline 23 & Chemical Technology & 1 \\
\hline 24 & Control and Automation Technology & 1 \\
\hline 25 & Logistics & 2 \\
\hline 26 & Mechatronics & 1 \\
\hline 27 & Accounting & 3 \\
\hline 28 & Accounting and tax practices & 2 \\
\hline 29 & Retail and Store Management & 1 \\
\hline 30 & Radio and Television Programming & 1 \\
\hline 31 & Management of health institutions & 1 \\
\hline 32 & Medical Documentation and Secretariat & 2 \\
\hline 33 & Medical Laboratory Techniques & 1 \\
\hline 34 & Medical Promotion and Marketing & 1 \\
\hline 35 & Medicinal and Aromatic Plants & 1 \\
\hline 36 & Tourism and Hospitality Management & 1 \\
\hline 37 & Tourism and hotel Management & 2 \\
\hline 38 & International Logistics & 1 \\
\hline 39 & Web Technologies and Programming & 1 \\
\hline & & 86 \\
\hline & & \\
\hline
\end{tabular}

Table 4: Distance learning undergraduate programs in Turkey (2012)

\begin{tabular}{|c|c|c|}
\hline Order & Program Name & Number \\
\hline 1 & Banking and finance & 1 \\
\hline 2 & Computer engineering & 2 \\
\hline 3 & Computer and Instructional Technology education & 1 \\
\hline 4 & Geography & 1 \\
\hline 5 & Contemporary Turkish Dialects and Literatures & 1 \\
\hline 6 & Labor Economics and Industrial Relations & 1 \\
\hline 7 & Econometrics & 2 \\
\hline 8 & Industrial Engineering & 1 \\
\hline 9 & Journalism & 1 \\
\hline 10 & Public Relations and Publicity & 1 \\
\hline 11 & Economy & 1 \\
\hline 12 & English Language and Literature & 4 \\
\hline 13 & Business Management & 1 \\
\hline 14 & Public administration & 1 \\
\hline 15 & Finance & 1 \\
\hline 16 & Maths & 1 \\
\hline 17 & Turkish language and literature & 1 \\
\hline 18 & Management information systems & 1 \\
\hline 19 & General Total & 1 \\
\hline 20 & & 28 \\
\hline 21 & Socounting Information Systems & 1 \\
\hline 22 & & 1 \\
\hline & Helevision and Cinema & 1 \\
\hline
\end{tabular}


The number of distance learning students in Kirıkkale University has increased rapidly since 2009. Table 5 shows these values. Our undergraduate students, like other universities in Turkey, takes some distance learning courses online These courses are generally Turkish Language, Foreign Language and Ataturk's Principles and History of Turkish Revolution. In this way, undergraduate students also entered and practiced in distance learning system. Kirıkkale University Distance Education Center (KUDEC) is the institution that provides distance learning services as it was planned according to our educational goal. The numbers shown in Table 5 are also KUDEC student numbers. According to the table, the number of students served by KUDEC has increased rapidly over the years.

Table5. Number of KUDEC students, virtual classroom and assignment

\begin{tabular}{|c|c|c|c|}
\hline Year & $\begin{array}{c}\text { Number of } \\
\text { Students }\end{array}$ & $\begin{array}{c}\text { Virtual } \\
\text { Classroom }\end{array}$ & Assignment \\
\hline 2014 & 3915 & 1685 & 3546 \\
\hline 2015 & 4352 & 1955 & 4965 \\
\hline 2016 & 5412 & 2134 & 5448 \\
\hline 2017 & 6234 & 4345 & 7545 \\
\hline
\end{tabular}

In Kirikkale University e-learning platform, concurrently 15 live classroom session can be given at the same time. Approximately 510 hours of virtual classroom lessons are given weekly for 250 courses and each session must be archived in a file for reuse and monitoring by the students. Nearly 200 megabytes of data per hour is produced in one virtual classroom session, it means that a course video file occupies about 150 to 400 megabytes, according to the length of the course session. In the first term of 2017, 1684 virtual classrooms were recorded. The volume of virtual classrooms stored in a term reached 336 gigabytes.

At least one assignment is given for each course. The assignment file, which the students send back for reviewing by tutor to the system, is about 40 kilobytes. Over the last four years, a 5064 megabytes assignment files have been stored.

\section{CONCLUSION}

Distance learning is of great importance for Turkey. The lack of formal education at the desired level and quality increased the value given to distance learning. As the number of students increases in formal education, it reduces the efficiency in the classroom. However, distance learning can provide more useful results in terms of individual development and can reinforce the transmitted information with audiovisual examples. At the same time, it enables individuals who are not able to attend school due to work or physical disability to receive education. The use of technological media tools, the Internet and the use of computer infrastructure have facilitated access to information, it has positively affected individuals of all ages or groups to receive education. At the same time, distance learning plays an important role in decreasing the cost of education by preventing many elements such as buildings, classrooms, teachers and educational materials that limit the student capacity to participate in the training and taking all these into consideration, it is seen how distance learning is valuable for economic and technological education. Distance learning services which have a long tradition in Turkey have provided the increase of individual success and the basis for a better quality of independent work.

\section{REFERENCES}

1. Z. Kaya, "Uzaktan Eğitim", Pegem A Yayınları, Ankara, Turkey, 2002.

2. S. Ryan, B. Scott, H. Freeman and D. Patel, The Virtual University. London: Kogan Page, 2000.

3. T. A. Ekinci, "The Demand Extent of Distance Education: A Qualitative Research from Managers' Perspective", Hacettepe University Journal of Education, vol.32, no.3, pp.745-759. 2017.

4. A. Bozkurta, “Türkiye'de uzaktan eğitimin dünü, bugünü ve yarını", Açıköğretim Uygulamaları ve Araştırmaları Dergisi, AUAd, vol.3, no.2, pp.85124, 2017.

5. İ. Abazaoğlu, H. Umurhan, "Uzaktan Eğitim ve Öğretim Üyelerini Uzaktan Eğitime Teşvik Eden Faktörler", Journal of Research in Education and Teaching, vol.4, no.4, Art.no.35, 2015.

6. C. Alkan, "Uzaktan eğitimin tarihsel gelişimi”, Türkiye 1. Uluslararası Uzaktan Eğitim Sempozyumu, 12-15 Kasım, Ankara, Turkey, 1996.

7. Y. Gelişli, "Uzaktan Eğitimde Öğretmen Yetiştirme Uygulamaları: Tarihçe ve Gelişim", Journal of Research in Education and Teaching, vol.4, no.3, Art.no.34, 2015. 
International Journal of Trend in Scientific Research and Development (IJTSRD) ISSN: 2456-6470

8. A. İşman, (2005). "Uzaktan Eğitim Ankara", 11. [Online]. Available: https://www.devlette.com/ Pegem A Yayıncilik.

9. S. Çoban, "Uzaktan ve Teknoloji Destekli Eğitimin Gelişimi”, XVII. Türkiye'de İnternet Konferans1, Anadolu Üniversitesi, Eskişehir, Turkey, 2012.

10. Ö. Özbay, “Dünyada ve Türkiye'de Uzaktan Eğitimin Güncel Durumu", The Journal of International Education Science, vol.2, no.5, pp.372-375, 2015. uzaktan-egitim-nedir-nasil-basvurulur-ucretlerinasildir/. [Accessed 1511 2018].

12. A. M. Kırık, "Uzaktan eğitimin tarihsel gelişimi ve Türkiye'deki durumu", Marmara University Journal of Communication, vol.21, pp.73-94, 2014.

13. E. Balaban, "Dünyada ve Türkiye'de Uzaktan Eğitim ve Bir Proje Önerisi", İstanbul Işık Üniversitesi, İstanbul, 2012.

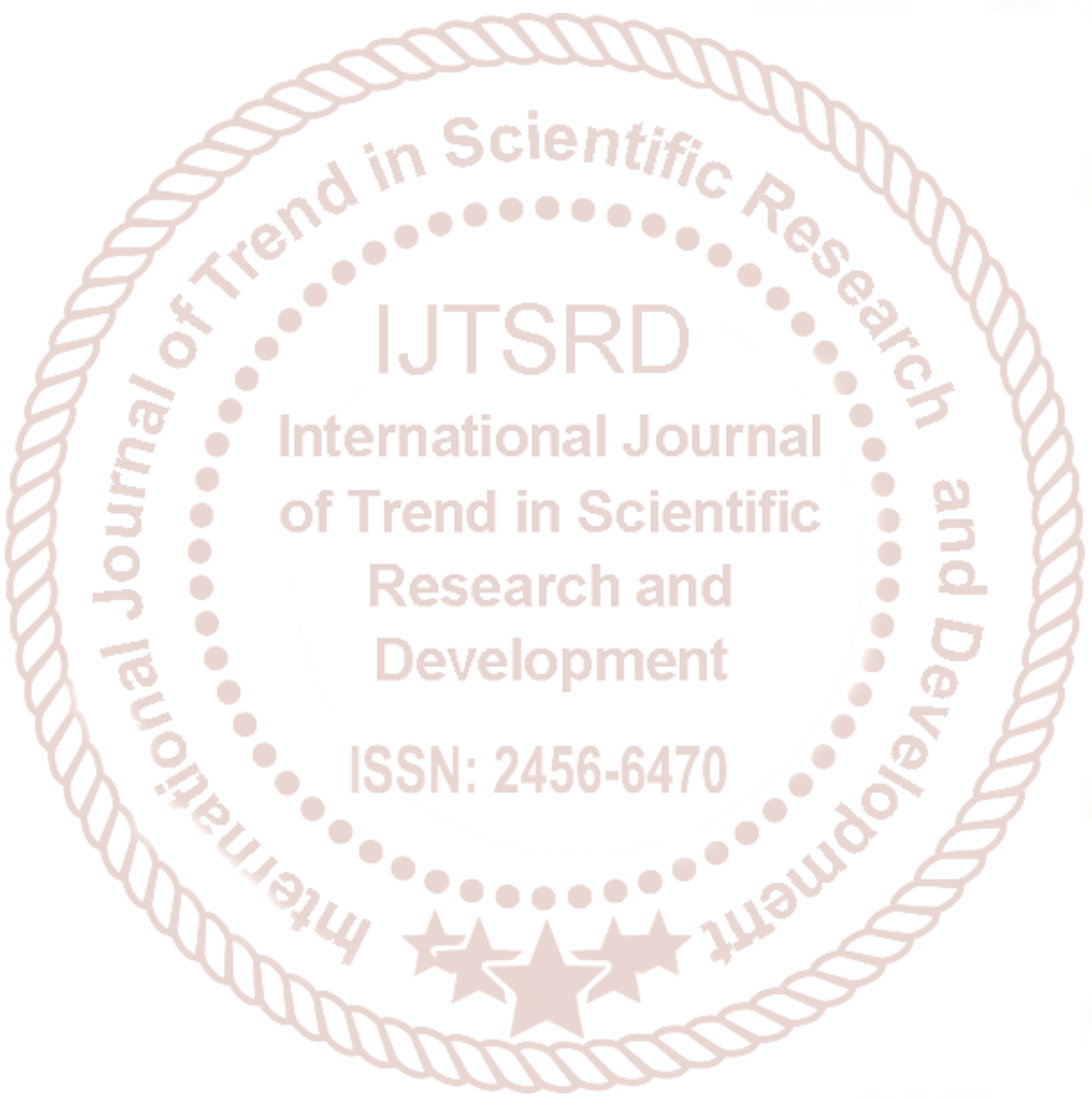

